\title{
Transformation of Ukrainian Automotive Industry in the Context of Electromobility: Applying the Experience of Visegrad States
}

\author{
Yevhen Savelyev $^{1 *}$, Vitalina Kuryliak ${ }^{1}$, Konstantia Darvidou $^{2}$, Mariia Lyzun ${ }^{1}$ and Ihor Lishchynskyy ${ }^{1}$, \\ ${ }^{1}$ Department of International Economics, West Ukrainian National University, 46009 Ternopil, Ukraine \\ ${ }^{2}$ University of Western Macedonia, 52100 Kastoria, Greece
}

\begin{abstract}
Ukrainian automotive industry. Its volumes neared insignificancy in 2020. The authors consider the issue of the industry's revival in the national economy. The basis of the concept is the creation of enterprises for the production of electric vehicles, including components, semi-finished products and accessories to them. It is suggested that investors can be attracted by developing cooperation of legislative and governmental institutions and local governments with world market leaders and taking measures to improve the national indicators in terms of the ease of doing business. It is proposed to focus the business philosophy of new enterprises on the use of vehicles rather than the field of production, as has been the case since the invention of the automobile. The choice of innovative areas should take into account the megatrends and use individualization, urbanization, artificial intelligence, mobility, digital culture, cooperation with other industries, offers of additional goods and services as its foundations.
\end{abstract}

\section{Introduction}

In 2021, Ukraine celebrates the 30th anniversary of its independence. In this time, the country's economy has undergone a transformation from a socialist system to a "trophy" in the hands of oligarchic economic actors. This happened when a small group of "new" entrepreneurs ("oligarchs" in the current terminology) captured large "trophies" - industries. This process was made possible because the privatization mechanism was adapted in such a way as to redistribute state property between the emerging oligarchs, which did not lead to the replacement of the less efficient owner (the state) with a more efficient one. As a result, Ukraine entered the 21 st century as a country with predominantly raw material exports and weak innovative industries that could have otherwise brought significant value added. According to the latest results of the International Comparisons Program, the level of Ukrainian GDP in 2017 was equal to 504.4 billion US dollars (as per PPP). Ukraine has a GDP per capita of $\$ 11,871$ PPP, which, in Europe and Central Asia, exceeds only Tajikistan and Kyrgyzstan.

Ukraine's long-term economic lag has various causes. However, the low level of development of the real economy, especially the processing industry is among the main, if not the main factor. The share of processing industry in the structure of gross value added has a steady downward trend and amounted to $11.6 \%$ in 2018 compared to $13.0 \%$ at the beginning of the decade (2010), and $19.4 \%$ at the start of the century.

This kind of deindustrialization determines the low level of competitiveness of the economy and requires the development of a radical strategy to increase the role of industry in GDP. The indicators of the world market leaders can serve as benchmarks. For instance, the share of industry in the structure of US GDP is $18.9 \%$, for Germany it is $30.15 \%$, for Great Britain - $19.0 \%$, for Norway - 31.1\%, for Sweden - 33.0\%, for France $19.1 \%$, and for Japan - 29.7\% [1]. Despite significant differences in these indicators (caused mainly by international specialization and the peculiarities of postindustrial development), they testify to the expediency of advanced industrial development as an important source of economic growth and job creation.

In order to determine the changes necessary to reverse the trend towards deindustrialization, the proverbial Gordian knot of Ukraine's economy must be found and cut before any significant influence on the country's GDP can be achieved. Today, the automotive industry is the "bottleneck" in the country's industrial sector. Its indicators over the last five years show an unfortunate trend: 2015 - 84.4\%; $2016-99.0 \%$; 2017 $116.6 \%$; $2018-115.3 \%$; and $2019-96.8 \%$. Within this industry, production of vehicles, trailers and semi-trailers is the weakest link, the indicators of which were respectively $94.4 ; 94.8 ; 111.6 ; 101.8$; and 74.3 .

However, the automotive industry is of great importance in the development of convergence of postsocialist countries and their European integration. This is evidenced by the experience of the Visegrad Four countries, which opened the market for multinational companies and created conditions for the development of knowledge-intensive industries. Their greatest success was the formation and development of mechanical engineering, especially in the automotive industry. In terms of vehicle production, the group is now a leader in the European and world economy. In the European

\footnotetext{
* Corresponding author: yev.savelyev@gmail.com
} 
Union, the Czech Republic ranks 5th, Slovakia 7th, Poland 8th and Hungary 9th. In the world market they have 17, 21, 22 and 23rd positions, respectively.

The experience of the Visegrad Four countries is important for Ukraine because the development of the automotive industry introduces them to a market with high effective demand, one that is changing rapidly and growing at the same time. The development of this industry leads to the creation of a large number of enterprises specializing in the production of parts, semifinished products and accessories, the provision of sales and logistics services. Most enterprises in the modern automotive industry can operate with up to 100 employees, which makes it possible to create jobs without creating large migration flows in the country. At the same time, tens, and over time, hundreds of thousands of jobs can be created in the industry. Finally, the technological capabilities of the automotive industry gradually form local, regional and international production networks, which become the basis for the country's inclusion in the system of European economic integration, as evidenced by the experience of the Czech Republic, Slovakia, Poland and Hungary.

\section{Analysis of recent research and publications}

The interest in the automotive industry has declined in the Ukrainian scientific literature in the last decade, which can be explained by the decline in domestic car production. However, despite the crisis in the automotive industry, there are publications that try to find the prospects for vehicle production in Ukraine. They are considered in terms of attracting foreign investment and increasing the competitiveness of the domestic model range, resource and infrastructure support necessary for the functioning of a competitive automotive industry and attracting the attention of investors, assortment policy transformations, state policy for the development of road transport market infrastructure [2;3]. A monograph by I. $\mathrm{Yu}$. Shevchenko offers a systemic view at the development of the automotive industry and a methodology for assessing the competitiveness designed by the author, as well as original spherical model and concept of the state program of industry development up to 2025 [4]. However, the author did not link their proposals to the use of market methods. The concept of competitiveness in a rapidly changing world economy was developed by Braja \& Gemnik-Salwach, who proved that the growing role of innovative and destructive technologies is one of the most important factors driving these processes, and knowledge-intensive and innovative industries have become the main drivers of economic growth and economic competitiveness [5]. In recent years, the development of methodological problems in the context of rapid changes in the world economy has been accelerating. In December 2020, the European Automobile Manufacturers' Association published Roadmap for the deployment of automated driving in the European Union, which discusses the benefits and terminology of automated driving [6]. In summary, the analysis of existent publications shows a lack of scientific research that would systematically solve the problem of overcoming the crisis of the automotive industry and position it as a renewed modern production subsystem of Ukraine's economy, an important step for a country with a focus on accelerating European integration.

The aim of the study is to develop proposals for the revival of the automotive industry in Ukraine based on the introduction of electric vehicle production and creation of local and regional production networks with their gradual integration into global production networks and value added networks.

\section{Research Results}

\subsection{Development of the automotive industry in the years of Ukraine's independence}

During the 90 s and the first decade of the 2000s, the automotive industry of Ukraine developed as a priority area that provided the solutions to social, economic, environmental, scientific, and technical problems while the market economy was still being established. About 90 thousand jobs were created in this industry and the same number of employees were engaged in related industries. After gaining independence, Ukraine had four plants for the production of vehicles, including cars (Zaporizhzhia and Lutsk), trucks (Kremenchuh) and buses (Lviv), and more than 60 companies that produced components.

Changes in the automotive industry that took place after Ukraine's independence, i.e. after 1991, were mainly precipitated by the relations with Russia. There were several assembly lines in Ukraine, including minibuses "Bogdan" in Cherkasy and cars "Volga" in Illichivsk (now Chornomorsk), low-tonnage cars "Gazelle" - in Simferopol and Lubny. These Russian car models were inferior in their competitiveness to Western brands and their production worsened the lag of the Ukrainian car industry in scientific, technical and innovative terms.

A relative success was achieved by the construction of the "Eurocar" plant for the production of VW Group cars near Uzhhorod, two kilometres from the border with Slovakia and Hungary, where there were global manufacturers of automotive components. In the context of the Eastern Partnership policy, equipment from the best European manufacturers "Transsystem" (Poland), "Chropynska Strojirna" (Czech Republic), "EISENMANN" (Germany) and others was provided to equip the enterprise. "Eurocar"'s innovativeness is also reflected in the uniqueness of software and technological innovations to ensure the flexibility of production processes. However, the plant managed to achieve only minimal profitability mainly due to limited orders of 10,000 cars, while the plant project was estimated for $50,000-100,000$ cars. The mistake of the company's founders was to bet on the Russian market, which in Ukraine is problematic for political reasons. 
Table 1. Production of cars and commercial vehicles in Ukraine in 2000-2019 [7].

\begin{tabular}{|l|l|l|l|l|}
\hline Year & Cars & $\begin{array}{l}\text { Commercial } \\
\text { vehicles }\end{array}$ & Total & $\begin{array}{l}\text { Change, } \\
\%\end{array}$ \\
\hline 2019 & 6254 & 1011 & 7265 & 9,7 \\
\hline 2018 & 5660 & 963 & 6623 & $-22,9$ \\
\hline 2017 & 7296 & 2296 & 9542 & 81,2 \\
\hline 2016 & 4340 & 924 & 5264 & $-36,1$ \\
\hline 2015 & 5654 & 2590 & 8244 & $-71,3$ \\
\hline 2010 & 75261 & 7872 & 83133 & 20,06 \\
\hline 2009 & 65646 & 3649 & 69295 & $-83,6$ \\
\hline 2008 & 400799 & 22328 & 423127 & 5,1 \\
\hline 2007 & 380061 & 22530 & 402591 & 39,7 \\
\hline 2006 & 274860 & 20400 & 295265 & 36,8 \\
\hline 2005 & 196722 & 19037 & 215759 & 15,4 \\
\hline 2004 & 179098 & 7792 & 186890 & 73,2 \\
\hline 2003 & 103000 & 4890 & 107890 & 100,6 \\
\hline 2002 & 50393 & 3380 & 53773 & 69,0 \\
\hline 2001 & 24995 & 6829 & 31824 & 1,8 \\
\hline 2000 & 18124 & 13121 & 31255 & 63,0 \\
\hline 1999 & 10136 & 9044 & 19180 & \\
\hline & & & & \\
\hline
\end{tabular}

Ukraine's automotive industry has tended to grow since the early 2000 s. In 2008 , the production peaked at 423,127 cars. Since 2009, the trend has changed to an annual decline. Initially, the cause was the global crisis of 2008-2009. In 2019, the volume of production amounted to 7265 units, which were manufactured mainly at the plant "Eurocar" (table 1). Added to this is Ukraine's accession to the World Trade Organization and the adoption of its terms to reduce import duties on foreign cars from $25 \%$ to $10 \%$ and the waiver of a number of preferences for domestic producers. At the same time, illegal schemes of importing cars with foreign registration spread. Later, the decline in production was affected by the low competitiveness of Ukrainian cars in Western markets. Simultaneously, Russia waged a trade war with Ukraine in the eastern markets. Common methods were stopping car carriers, banning transit to Kazakhstan, blocking transit routes to the markets of Central Asia and the Caucasus.

\subsection{Revival of the automotive industry of Ukraine: priority conceptual components}

The crisis of the automotive industry of Ukraine has led it to a state that can be assessed as approaching zero. Therefore, there are grounds make reviving the industry a priority, as a country with an area of 607 thousand $\mathrm{km} 2$ and a population of more than 40 million, should not exist without its own automotive industry.

The problem of the revival of the automotive industry should not be understood as a matter of modernization or renewal of bankrupt enterprises. The task should be to establish modern production by corporate and private owners of the latest scientific and technical achievements in the automotive industry. It is clear that the latter will drive a hard bargain, to which the state must generally agree. It can be argued in advance that they will prioritize radical reforms of the judiciary and anti-corruption measures to ensure the security of their businesses. According to V. P. Prykhodko, "safe" investments create an opportunity to make capital investments and production savings at a level that guarantees sufficient rates of expanded reproduction, technological re-equipment and restructuring of the economy, which directly increases the potential protection of economic interests from threats of various origins. Given the scale of the project, creating an investment security mechanism is necessary to attract related producers as major investors.

Carrying out a large-scale transformation in the economy with the involvement of investors and world market leaders involves the implementation of measures to achieve good indicators in terms of the ease of doing business, since this indicator serves as a guide for making positive decisions about choosing a country for capital investment. Theoretically, it is considered a herald of socio-economic wealth [8]. Improving business conditions is particularly important for Ukraine, as it has never been ranked in the top 100 countries in the Ease of Doing Business Index compiled by the World Bank since 2006. However, in 2020 there was a significant improvement in this regard - Ukraine rose to 64th place in the ranking. Now there are reasons to establish a firmer place in the first hundred and continue to further increase the rating.

\subsection{Global competition at the start of the revival of Ukrainian automotive industry}

The world automotive industry is now on the verge of revolutionary changes. According to experts, by 2025, traditional automakers and suppliers should refocus on the challenges of global trends in electric mobility and significantly increase investment in the transformation of their business models. New competitors with new thinking and ideas will enter the market. This is in addition to the fact that, according to expectations, by 2030 more than $55 \%$ of new cars can be fully electrified, and in general, $95 \%$ of sales of new vehicles will have at least partial electrification. Moreover, up to $40 \%$ of mileage in Europe will be carried out by autonomous vehicles (without a driver) [9].

The drivers of change in the automotive industry are largely the technically well-educated young adults. It is the youth that should become the driving force behind the development of more sustainable and convenient scientific and technical solutions. They will have to rethink the whole system of economic relations in the industry, focusing not on the field of production, as has happened since the invention of the car and still continues to happen today, but on the use of vehicles. Given the megatrends, the choice of innovative areas will be based on individualization, urbanization, artificial 
intelligence, mobility, digital culture, cooperation with other industries, offers of additional goods and services. Given these trends, the European vehicle fleet is projected to decline from 280 million to 200 million units by 2030 [9].

Inclusion of Ukraine in competition with existing car manufacturers will happen in conditions of the difficult transition of existing enterprises to a new dimension. Many market leaders, including the Visegrad Four, end their production cycle in 2023, complicating the transformation process. Transnational corporations are choosing markets with cheaper labour for new investments. There are several economic studies showing that companies are considering moving production to countries with cheaper labour after the average wages in the region exceeds 1,200 euros [10].

In the context of transformation, the competition on the market is influenced by the fact that the cost of labour in the Eurozone is higher than in other countries. This encourages investors to look for alternatives to invest in. Among Ukraine's western neighbours, such a situation is emerging in the Visegrad Four. Slovakia, which is the only member of the Eurozone, has higher salaries than the rest of the Group, which is why in 2018 it lost the construction of a new BMW plant to its neighbour Hungary. At the same time, Budapest won the research contract for Jaguar Land Rover, despite the fact that in 2018 the company commissioned the only European plant outside the UK near the Slovak city of Nitra. Simultaneously in the neighbouring Czech Republic, BMW is building a research centre to test the management of autonomous vehicles. According to the Slovak Automobile Industry Association, the country has lost its competitiveness in the Visegrad Four region and is losing its advantage over the countries of Southern Europe [10].

Financial and economic readiness to start transformational changes is an important factor in competition in the automotive industry today. At the moment, it is not profitable for the owners of existing enterprises to restructure their production facilities to produce electric cars. They require a lag of time during which the most expensive assets can be depreciated, namely plants for the production of internal combustion engines and gearboxes. Under such conditions, outsider countries have obvious competitive advantages - they have nothing to lose. In view of this, it can be argued that Ukraine, given the entry of a strong investor in its market due to the time factor has a good chance of becoming an automotive state.

Thus, international competition in the field of car production is characterized by the accumulation of sufficient scientific and technical potential to carry out restructuring on market terms. Both current leaders in the automotive business and outsiders have a chance to compete for success in the vehicle market. Given the high cost of future transformations, their success will depend to a large extent on the interest and participation of governments. In this regard, it should be noted that the automotive industry is not a leader in investing in R\&D. The top 10 companies in the world in terms of $R \& D$ costs include only Tesla Motors, which spends \$ 0.7 billion (ranked 10th), while the spending of Alphabet (ranked 1st, specializing in software and internet) amounts to 12.3 billion dollars. At the company level, the prerequisite for success will be the choice of production location on the basis of a competent assessment of the factors of spatial, human, raw material and environmental potential. The final decision should be made taking into account the cooperation with central governments and local authorities.

\subsection{Avenues for revival of the automotive industry of Ukraine}

The revival of the automotive industry is a decade-long task of national importance, because it fundamentally changes the structure of the economy and convergence strategy, affects social institutions and the development of society. The scale of the task should be ensured from the very beginning by the adopted legislative and governmental actions. The experience of Poland is very significant in this context, as in 2003 it was among the top three countries offering the best conditions for the location of plants for the production of components for the automotive industry. This was followed by an increase in FDI inflows and the development of a subsupplier reserve, and during 2007-2009 Poland became the second largest (after the Czech Republic) car manufacturer in Central and Eastern Europe [11].

The central government should initiate the invitation of the main investor. It is advisable to attract a multinational company that owns the brand with top sales in the Ukrainian market, namely Toyota, Renault, Skoda, Nissan, Hyundai, or Volkswagen. Regulatory documents should regulate the allocation of land for the creation of industrial zones to the parent company and manufacturers of parts and semi-finished products.

The global trend of transformation of the automotive industry indicates the impossibility of success without the use of public-private partnership. For example, the Automobile Industry Association of Slovakia appealed to the government to conclude a Memorandum of Understanding and Cooperation on creating conditions for sustainable development of the industry. This document should help maintain the competitiveness of the automotive industry in the long run. For Ukraine, which is developing the industry after the fall in production to almost zero, success without close cooperation with central government agencies is almost impossible.

Along with the choice of the main investors and the model range of the cars, it will be necessary to decide on the division of labour. The automotive industry in the narrow sense is a component of mechanical engineering. However, its functioning requires the creation of a kind of symbiosis of mechanical engineering, electrical and chemical industries. To ensure the production of components, the parent company must create a network of related companies and global suppliers. Given the global experience, generally for this purpose cooperation with small and medium-sized businesses, most of which have of $25-50-100$ employees is established and 
developed. The developed system of automobile production has hundreds of subcontractors. In Slovakia, for example, there are about 700 companies operating in the automotive industry [12].

The creation of an enterprise for the production of electric vehicles will require the development of technology of numerous components for a new type of product. These include autonomous control systems, alternative drives, digital data transmission, braking systems, lane keeping assistance systems, medium capacity batteries that are charged through recuperation during braking, batteries for plug-in hybrids.

The division of labour among car manufacturers forms the geographical structure of the automotive industry. Local, regional and global production networks are created for the purposes of balanced and synchronous functioning of producers. However, this process of division of labour should not be final. Today, in the real economy, more and more attention is paid to global value-added networks. They make it possible to distribute individual production operations between different countries of the world, which is a means of ensuring a high level of competitiveness [13]. For Ukraine, this requires finding forms of cooperation with the Visegrad Four. They are, firstly, territorially the closest countries of the European Union, and, secondly, world leaders in the automotive markets. The formation of international production networks and global valueadded networks in Central and Eastern Europe with the participation of Ukraine can be an effective direction for successful and accelerated development of the country's automotive industry

\section{Discussion and conclusions: car production, a new business model - a new community}

Revival of the automotive industry of Ukraine is a road from deindustrialization to industrialization of the country following the newest scientific and technical ideas focused on the future. That is why an electric car with different levels of automation and digitization should be the basis for this process. The mission of the automotive industry is changing rapidly, it can no longer be traditionally interpreted as meeting the growing needs of the population in mobility and approaching the level of economic prosperity of developed countries. At the same time, electrification in combination with digitalization encourages the establishment of new social relations and a new way of life. We do not deny the importance of traditional innovations: economical engine, reliable brake mechanism, high-speed car, attractive design, etc. However, in time there is a need for new innovations, such as autonomous driving and automated cars.

A comprehensive and rapid reorganization of the automotive sector will result in the emergence of new business models. Manufacturers and suppliers must offer consumer-oriented innovations to succeed in the markets. It should be assumed that a certain part of society, especially young people, does not have and does not need a personal car. Multinational companies are already developing models that will be effective in online car-sharing agencies to create driving communities on online platforms with intermediary functions for private travel. The greatest prospects are predicted for business models of car sharing in large cities, combined with public transport. Modern electric cars have great potential to create an inclusive society and expand opportunities for equal participation in public life, in particular with the use of a car without a driver.

Electric mobility experts are developing new concepts based on the fact that the future of the car is the future of mobility. Discussions on such a link are important for developing an automotive strategy. The development of the debate on the future of the automotive industry in the global dimension and in Ukraine in particular can be conducted based on new terminology: the coefficient of integration, infrastructure efficiency, inventory ratio and levels of autonomy.

Achieving the goal of reviving the automotive industry is a task of at least a decade for Ukraine. It will be impossible to do without reorienting the training of engineering and technical personnel for the production and maintenance of equipment of the future. Ukraine had a competitive engineering education in the Soviet system. Its comparative advantage lay in the harmonious combination of two main components - educational and scientific. However, it operated separately from manufacturing entrepreneurship and global innovation trends. In recent years, the government has increased government orders for engineering training. However, the increase in the number of specialists alone is not able to sufficiently ensure the country's international competitiveness in the context of the transformation of the world economy to the requirements of Industry 4.0.

The reform approach to engineering training should be based on the fact that Industry 4.0 will operate in a new economy that not only necessitates transformation, but may also pose a threat [14]. Engineers need to be able to implement a new approach to production, fully linking physical work to the digital world, automating processes and allowing machines to operate independently. Despite the view of the job automation's limited effect [15] (for Germany), most researchers predict a significant impact on employment and / or wages ([16] for the US; $[17,18]$ for six EU countries). It is proved that the pace of implementing the achievements of Industry 4.0 will vary in different industries and countries. Therefore, it can be argued that it will be determined by the readiness of the engineering to create and develop innovations.

If a new system of engineering training is to be created, it must be included in the processes of creating clusters, technology parks, business incubators, design bureaus, and small businesses. Accordingly, the diploma on engineering education should reflect the level of knowledge, practical skills, creative (innovative) potential of the university graduate. Such a model can be implemented in the framework of dual education, the implementation of which has begun in Ukraine, but does 
not yet have a sufficient scientific, methodological and regulatory background.

\section{Acknowledgements}

This article was prepared in the framework of cooperation on the research topic ME-05-2019 "B" "Creating the alliance of Poland, the Czech Republic, Slovakia, Hungary and Ukraine as the Visegrad Five: the context of regional economic integration", which is undertaken by West Ukrainian National University (WUNU) with the financial support from the State Budget of Ukraine. However, the support of WUNU is not an automatic support of the article's content, which reflects only the views of the authors. WUNU is not responsible for any use of the information provided in the article.

\section{References}

1. A. O. Zadoia, De stvoriuietsia VVP, abo industrializatsiia chy deindustrializatsiia? (Where is GDP created, or industrialization or deindustrialization?). European vector of economic development. 2(23), 27-41 (2017)

2. O. V. Boiko, V. V. Koval, in Proceedings of the International Scientific and Practical Conference "Development of Trade and Entrepreneurship in Ukraine: Trends and Prospects", Odessa, 2017. http://www.otei.odessa.ua/wpcontent/uploads/2017/11/\%D0\%97\%D0\%B1i $\% \mathrm{D} 1$ $\% 80 \% \mathrm{D} 0 \% \mathrm{BD} \% \mathrm{D} 0 \% \mathrm{~B} 8 \% \mathrm{D} 0 \% \mathrm{BA} \% \mathrm{D} 0 \% 9 \mathrm{C} \% \mathrm{D} 0$ $\% 9 \mathrm{D} \% \mathrm{D} 0 \% 9 \mathrm{~F} \% \mathrm{D} 0 \% 9 \mathrm{~A} \_25.05 .2017$.pdf\#page $=33$

3. I. Yu. Shevchenko, Harmonizatsiia yak novitnii pidkhid do derzhavnoho rehuliuvannia rozvytku malosubiektnykh haluzei natsionalnoi ekonomiky (na prykladi avtomobilnoi promyslovosti Ukrainy). International scientific and practical conference, November 2020, 27-28. doi:10.30525/978-9934-26005-6-4

4. I. Yu. Shevchenko, Rehuliuvannia rozvytku avtomobilebuduvannia Ukrainy: monohrafiia (Regulation of automobile development of Ukraine: monograph). (Kharkiv: KhNADU, 2019), p.556

5. M. Braja, A. Gemzik-Salwach, Competitiveness of high-tech exports in the EU countries. Journal of International Studies. 13(1), 359-372 (2020). doi:10.14254/2071-8330.2020/13-1/23

6. European Automobile Manufacturers Association, Automated driving. Roadmap for the deployment of automated driving in the European Union. (ACEA, 2020),

https://www.acea.be/uploads/publications/ACEA_A utomated_Driving_Roadmap.pdf. Accessed 14 Dec 2020

7. International Organization of Motor Vehicle Manufacturers. Production statistic. https://www.oica.net/production-statistics/. Accessed Jan 142021
8. A. L. Leal-Rodríguez, C. Sanchís-Pedregosa, Could the Ease of Doing Business Index be considered a predictor of countries' socio-economic wealth? An empirical analysis using PLS-SEM, 12(4), 229-243 (2019) doi:10.14254/2071-8330.2019/12-4/15

9. F. Kuhnert, Ch. Stürmer, A. Koster, Five trends transforming the Automotive Industry.

(PricewaterhouseCoopers GmbH Wirtschaftsprüfungsgesellschaft, 2018) https://www.pwc.at/de/publikationen/branchen-undwirtschaftsstudien/eascy-five-trends-transformingthe-automotive-industry_2018.pdf. Accessed 12 Dec 2020

10. B. Toma Ako Detroit? Domáci automobilový priemysel čakajú posledné dobré roky (2020). https://ekonomika.pravda.sk/firmy-atrhy/clanok/538578-koniec-ako-detroit-domaciautomobilovy-priemysel-cakaju-posledne-dobreroky/ Accessed Dec 122020

11. Wikipedia, Przemysł motoryzacyjny w Polce. 2021. https://pl.wikipedia.org/wiki/Przemys\%C5\%82_mot oryzacyjny_w_Polsce. Accessed 15 Jan 2021

12. Udržatel'nost' automobilového priemyslu na Slovensku. MôjElektromobil. 2019. https://www.mojelektromobil.sk/elektromobilita/infr astruktura/nabijacie-stanice/ Accessed 16 Dec 2020

13. L. Slušná, M. Balog et al., Automobilový priemysel na Slovensku a globálne hodnotové ret'azce Slovenská inovačná a energetická agentúra (Bratislava, 2015). https://www.siea.sk/wpcontent/uploads/files/inovacie/publikacie/studia_Aut omobilovy_priemysel_na_Slovensku_a_globalne_h odnotove_retazce_SIEA_web.pdf. Accessed 14 Dec 2020

14. S. Szabo, Transition to Industry 4.0 in the Visegrád Countries. (Luxemburg:European Union, 2020).

15. W. Dauth, S. Findeisen, J. Südekum, N. Wößner, German robots - the impact of industrial robots on workers. IAB Discussion Paper No. 30/2017, (Institute for Employment Research, 2017)

16. D. Acemoglu, P. Restrepo, Robots and jobs: evidence from US labor markets. NBER Working Paper No. 23285, (2017)

17. F. Chicago, G. Petropulous, D. Pichler, The impact of industrial robots on EU employment and wages: a local labour market approach. Bruegel Working Paper, 2, (2018)

18. Belhadi, A., Kamble, S., Jabbour, C. J. C., Gunasekaran, A., Ndubisi, N. O., \& Venkatesh, M. (2021). Manufacturing and service supply chain resilience to the COVID-19 outbreak: Lessons learned from the automobile and airline industries. Technological Forecasting and Social Change, 163, 120447. 